\section{Frosty US visa policy leaves Indian science cold}

\section{NEW DELHI}

Scientific cooperation between India and the United States has been dented ahead of US President George Bush's official visit to New Delhi next month. Bush will find India's scientific community in a bitter mood following the United States' failure to give a visa to a leading Indian organic chemist on the suspicion that his work could be related to chemical warfare.

Bush was already preparing to deal with a nuclear establishment unwilling to separate its military and civilian atomic facilities the way Washington wants, a principle at the centre of last July's historic deal for nuclear cooperation between the two countries (see Nature 436, $446-447 ; 2005)$. But the visa issue is creating a new wave of resentment.

Goverdhan Mehta, a former director of the Indian Institute of Science (IISc) in Bangalore, had been invited as a visiting professor to the University of Florida at Gainesville, but says he was asked to prove that he was not working on chemical weapons before a visa was issued.

Mehta does not seem to have been singled out - the US Embassy in New Delhi said in a statement that it is "obliged to obtain sufficient information necessary for evaluating each application". But Indian scientists attempting to visit the United States on
"If the United States wants cooperation it cannot humiliate our scientists."

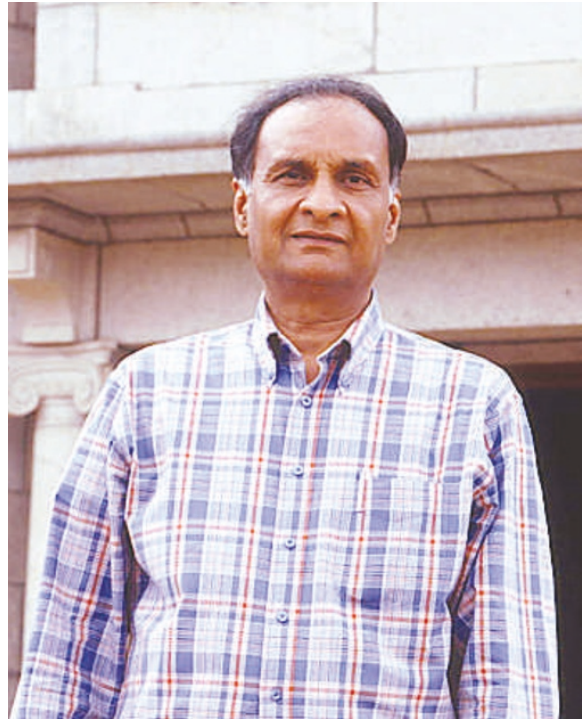

Security risk? Goverdhan Mehta was asked to prove he wasn't working on chemical weapons.

vaccine action programme but have decided only to attend the panel meetings in India."

C. N. R. Rao, science adviser to India's prime minister, says he agrees that visa applications need to be scrutinized, but doesn't see why it can't be done more tactfully. "I have decided never to attend an interview for a visa," he says.

India's science secretary Valangiman Ramamurthi warns that the United States stands to lose out on collaborations. For instance, he claims that India's interest in the International Linear Collider project "has come down tenfold because our team could not attend a workshop in the United States due to visa problems".

Samir Brahmachari, director of the Institute of Genomics and Integrative Biology in Delhi, says he was bodysearched at an airport in New York last year, despite having a sabbatical or to attend conferences say that the eight-week 'enquiry' period is demeaning.

"This is too much," says Mehta, who is a member of the Indian prime minister's science advisory panel and president of the Parisbased International Council of Science, which is committed to the free movement of scientists. "If the United States wants science cooperation with India it cannot humiliate our scientists the way I was treated by its consular officials."

Many Indian researchers have now withdrawn from the process altogether. "As a matter of principle I have stopped going to the United States," says biochemist Govindarajan Padmanaban, another former director of the IISc. "I am on the panel of the Indo-US diplomatic passport. "I have suggested that the IISc should cut off all US collaboration," he says. "As for myself, I have decided not to go to the United States. My institute is looking to China, Japan and Taiwan for research collaborations."

Officials at the US Embassy in New Delhi say it is not US policy to comment on individual visas. But in a statement released on 18 February, they said: "At the United States mission in India, certain cases involving hightechnology issues require review before consular officers are authorized to issue a visa. This review does not in any way dilute the US government commitment to building a science and technology partnership with India."

K. S. Jayaraman
ON THE RECORD

“Tell Larry he better appreciate my financial support."

Harvard student Vikram Viswanathan joins an online betting pool on whether embattled university president Larry Summers will announce his resignation by 30 June.

'Native peoples were either living in harmony with nature or eating their way through a vast array of largesized, attractive prey species."

University of Utah archaeologist Jack Broughton questions whether early Native Americans were at one with nature.

Sources: The Harvard Crimson, Reuters

\section{SCORECARD}

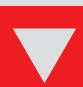
Hawaiian holidays The island of Maui may soon run out of sand. Mining sand for concrete is removing the only source for replenishing Maui's beaches.

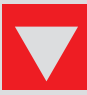
Raves Mixing the club drug ecstasy with loud music dramatically reduces brain function compared with popping a pill in peace and quiet, according to a study in rats.

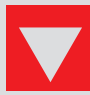

The munchies A drug that works by blocking a cannabinoid receptor in the brain may help to stop food cravings.

\section{NUMBER CRUNCH}

Is data secrecy hurting the next generation of life scientists? A recent survey of 1,077 doctoral students found that:

$\mathbf{2 3} \%$ had asked for and been denied access to data associated with published research.

$\mathbf{8} \%$ had denied other scientists access to data associated with their own published research.

$51 \%$ reported that data secrecy had hindered their research.

Source: C. Vogeli et al. Acad. Med. 81 137-145 (2006) 